\title{
IMPROVEMENT OF THE SYSTEM FOR ACCOUNTING OF PARAMETERS DURING CONSTRUCTION OF MOTOR ROADS
}

\author{
Elena Kurakina', Sergey Evtyukov² \\ 1,2 Saint Petersburg State University of Architecture and Civil Engineering \\ Vtoraja Krasnoarmejskaja ul. 4, St. Petersburg, Russia \\ 1elvl_86@mail.ru
}

\begin{abstract}
In the article, a necessity to improve the system for accounting of parameters for additional factors of technical condition of vehicles and road environment facilities allowed for during design and construction of motor roads is substantiated. A procedure for the determination of circumstances and causes of road accidents, taking into account transport, technical and operating conditions, has been developed. An improved algorithm of expert examination with the application of a non-destructive method with use of diagnostic equipment of dynamic impact is offered.

The accounting system includes an algorithm of expert examination of road accidents which provides parametric characteristics of objects and conditions for their existence to ensure procedure functioning. Criteria to identify "weak"sections of motor roads are proposed. A model for the implementation of expert examination taking into account parameters of the subsystem "Vehicle-Road" is proposed. A possibility to determine the risk of road accidents, "weak" sections of operated motor roads, development of an automated data base on motor roads, application of research results in expert opinions upon analysis and reconstruction of road accidents is substantiated.
\end{abstract}

\section{Keywords}

Motor road, road surface, vehicle, parameters, expert examination of road accidents.

\section{Introduction}

Improvement of the system for parameters accounting in construction of motor roads is based on the introduction of additional factors of technical condition of vehicles and road environment facilities allowed for during design and construction of motor roads in expert examination. Expert examination represents a set of successive systematic theoretical and practical methods or actions aimed at identifying the causes and factors that led to a failure in the Driver-Vehicle-Road-Environment (DVRE) system. A failure in the system means operating trouble of one of the key components, i.e. Vehicle, Driver, Road or their combinations, including the Environment component, which, in their turn, cease to perform their assigned functions partially or totally, leading to violations in safe operation of the entire system. Analysis of operating troubles or failure prevention are possible through qualitative expert examination. Scientific studies of some parameters of the subsystem "Vehicle-Road" condition, performed by scientists Nemchinov M. V., Vasiliev A. P., and Domke E. $\mathrm{R}$., are aimed at braking performance and characteristics of wheel adhesion with the road surface during operation and reconstruction of the latter (Nemchinov, 1985; Vasiliev, 2005; Domke, 2012; Kurakina, Evtyukov, 2015). Scientists Suvorov Yu. B., Kikot I. M. and others (Suvorov et al., 1990) were engaged in diagnostic studies of elements of operated motor roads at sections where road conditions affected traffic safety. Kiryukhin G. N. proved the relevance of road surface diagnostics and determination of traffic flow characteristics with the use of a wide range of devices and equipment for testing and diagnostics of motor roads (Kurakina, 2017; Kurakina et al., 2017).

Expert studies are supported by various procedures, algorithms, methods, strategies, techniques and equipment, depending on the purpose of the expert study, its complexity and the number of questions posed. Subjects of various researches are reviewed in works of such scientists as Borovskiy B. E., Ilarionov V. A., Evtyukov S. A., Zamarayev I. V., and Stolyarov V. V. (Ilarionov 1989; Evtyukov, Vasiliev, 2012). However, during construction, the system of accounting for the main parameters of the subsystem "Road" is specified by regulatory documents of the 
construction industry. Mutual complex study of the condition of "Vehicle-Road" subsystem parameters should be carried out at all stages of construction, operation and reconstruction in order to prevent emergency conditions (Kurakina, Evtyukov, 2017; Kurakina et al., 2017; Kurakina, 2014a; Kurakina, Evtyukov, 2014).

The potential for improvement of the system for parameters accounting during construction of motor roads is aimed at applying the procedure of road and transport expert study in a non-destructive manner. Application of the proposed procedure is also possible on operated sections of motor roads. The field of its application includes road accident expert examination and technical expert examination of motor vehicles, as well as analysis of road surface condition parameters and determination of its residual life.

\section{Subject, tasks and methods}

The study subject is parameters of ground transport and road infrastructure facilities' condition.

The study tasks include the following:

- obtaining actual data on the parameters of the "Vehicle-Road" subsystem condition with the use of modern automated multifunctional diagnostic equipment;

- development of a procedure and its algorithm to improve the reliability of determining circumstances and causes of road accidents, and, therefore, the accuracy of calculations in expert opinions;

- identification of "weak" sections of motor roads;

- development of a data base on motor roads with account for the studied parameters of the "Vehicle-Road" subsystem condition, affecting the risk of road accidents, determining places of possible accidents, and the development of activities for their timely prevention.

Methods for implementing the set tasks include methods of analysis of properties and opportunities for improvement of complex multifunctional systems, such as static and systematic methods, mathematical methods, computational methods, probability theory, data processing theory with regard to research results, and information technologies.

\section{Results and discussion}

In order to provide methodological support of the road accident expert examination algorithm, it is necessary to take into account parametric characteristics of objects and conditions for their existence to ensure procedure functioning. First of all, it is necessary to consider that expert studies are carried out on the roads of categories IA, IB, IC, II, III, IV, V and take into account characteristics and conditions established mostly during the construction of motor roads:

- geometry of road environment facilities (GREF);

- transport and operating conditions (TrOC);

- technical and operating conditions (TechOC);

- characteristics of road infrastructure facilities (CRIF).
Obtaining information about GREF, TrOC, TechOC, and CRIF is possible be means of analytical, diagnostic and computational methods of obtaining and processing parametric characteristics (Kurakina, 2014b, 2014c, 2015).

Mathematically, the model of expert study procedure implementation with account for parameters of the "Vehicle-Road" subsystem can be represented in the following form:

$$
\mathrm{Y}=f(\mathrm{X})
$$

where $X$ - parameters applied and obtained during the study.

Taking into account methods of obtaining and processing of parameters during the study, the value $X$ of the sum of all characteristics and conditions can be represented in the following form:

$\left\{\begin{array}{c}\sum_{i=1}^{n} X^{A}=f\left(x_{i}^{A}\right) \\ \sum_{i=1}^{n} X^{D}=f\left(x_{i}^{D}\right) \\ \sum_{i=1}^{n} X^{C}=f\left(x_{i}^{C}\right)\end{array}\right\}$

where $f\left(x_{i}^{A}\right)$ are parameters, their characteristics and conditions determined analytically, i.e. $f\left(x_{i}^{D}\right)-$ diagnostically and $f\left(x_{i}^{C}\right)$ - with computational methods, $i$ - the number of obtained values of the studied parameters.

Taking into account 2 equation, we obtain a set of values of parameters, obtained during road accident investigation with analytical, diagnostic and computational methods.

Therefore, taking into account 1 equation and parameters to be determined, the accounting during expert study, involving numerous parameter values, will be characterized by parameters involved in the study.

Evaluation of parametric characteristics of objects and conditions represents an expert opinion on the results of the study aimed at the following:

- determination of a technical possibility to prevent road accidents;

- compliance of the obtained values of vehicle and road infrastructure condition parameters with the requirements of legal documents;

- identification of "weak" sections of motor roads;

- determination of road accident risks;

- development of an automated road data base (ARDB) on "weak" sections.

The studied parameters of the technical condition of vehicles and road infrastructure are grouped into blocks included into the general algorithm of the expert study in a non-destructive manner. 


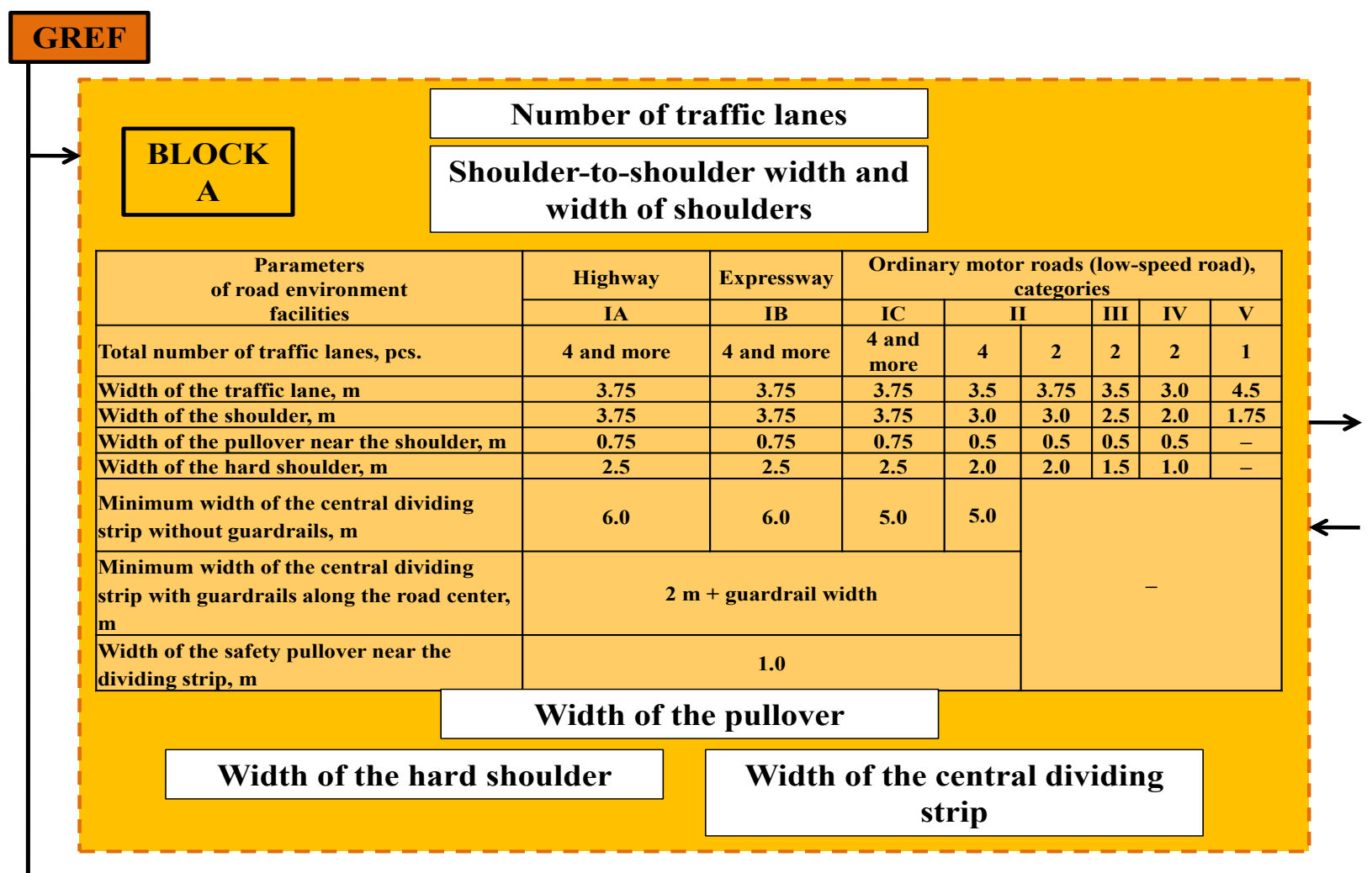

Figure 1a. Block A parameters: number of traffic lanes, width from shoulder to shoulder and shoulder width, width of the pullover, hard shoulder and dividing strip

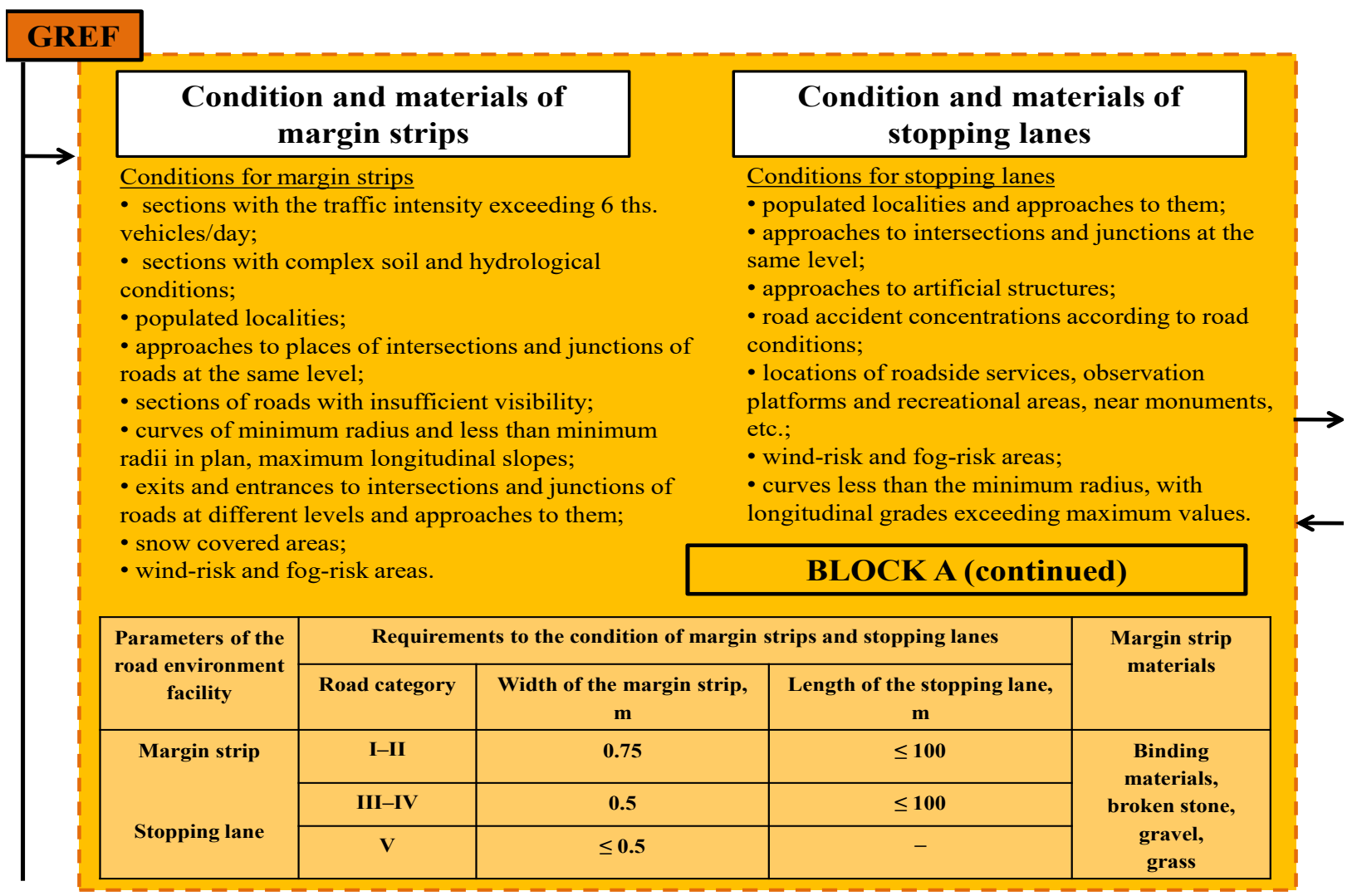

Figure 1b. Block A parameters: condition and materials of the margin strip and stopping lane 


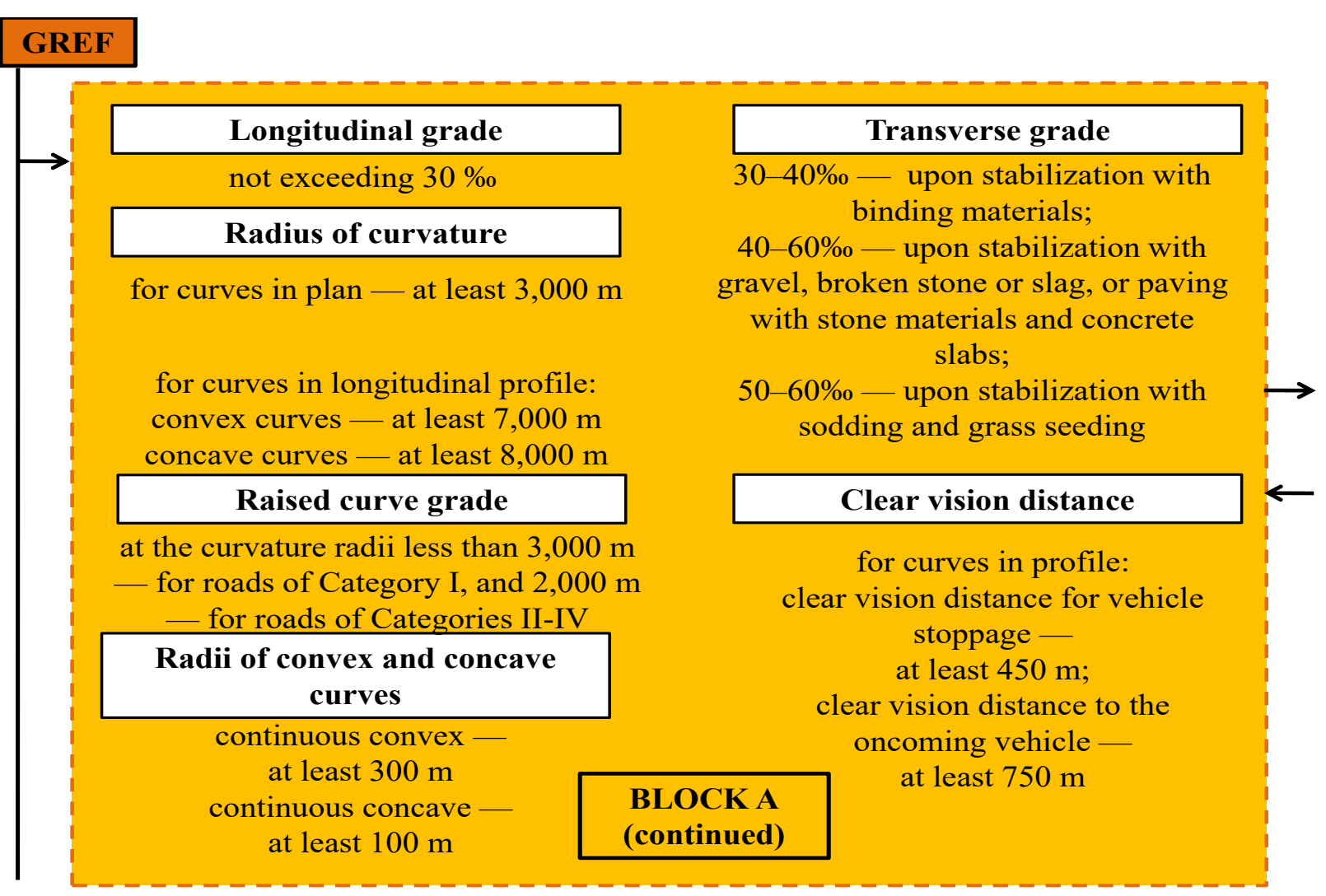

Figure 1c. Block A parameters: longitudinal and transverse grades, raised curve grade, curvature radius, convex and concave curves, clear vision distance

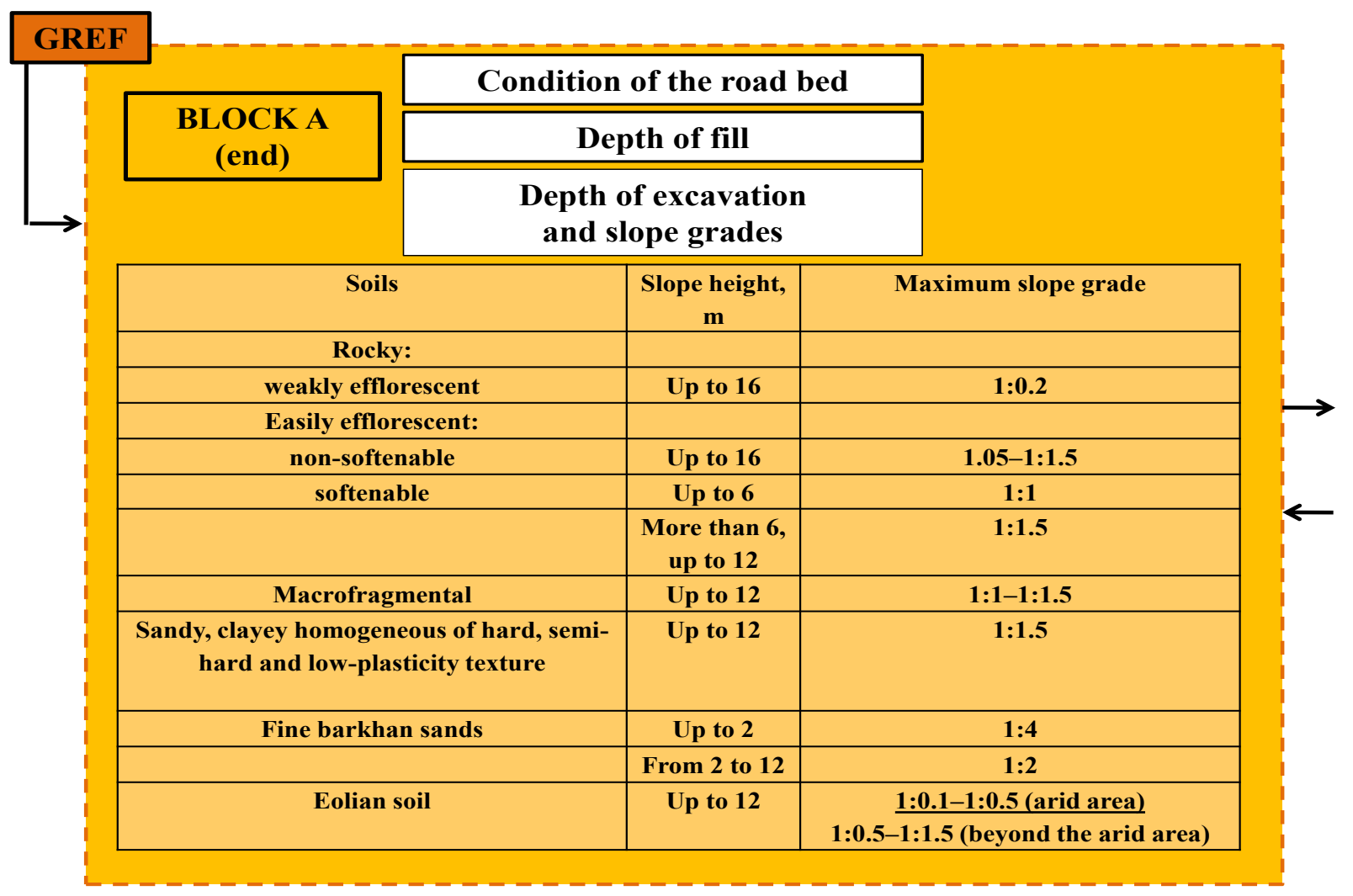

Figure 1d. Block A parameters: condition of the road bed, depth of fill, depth of excavations, slope grade 


\section{Architecture and Engineering Volume 2 Issue 3}

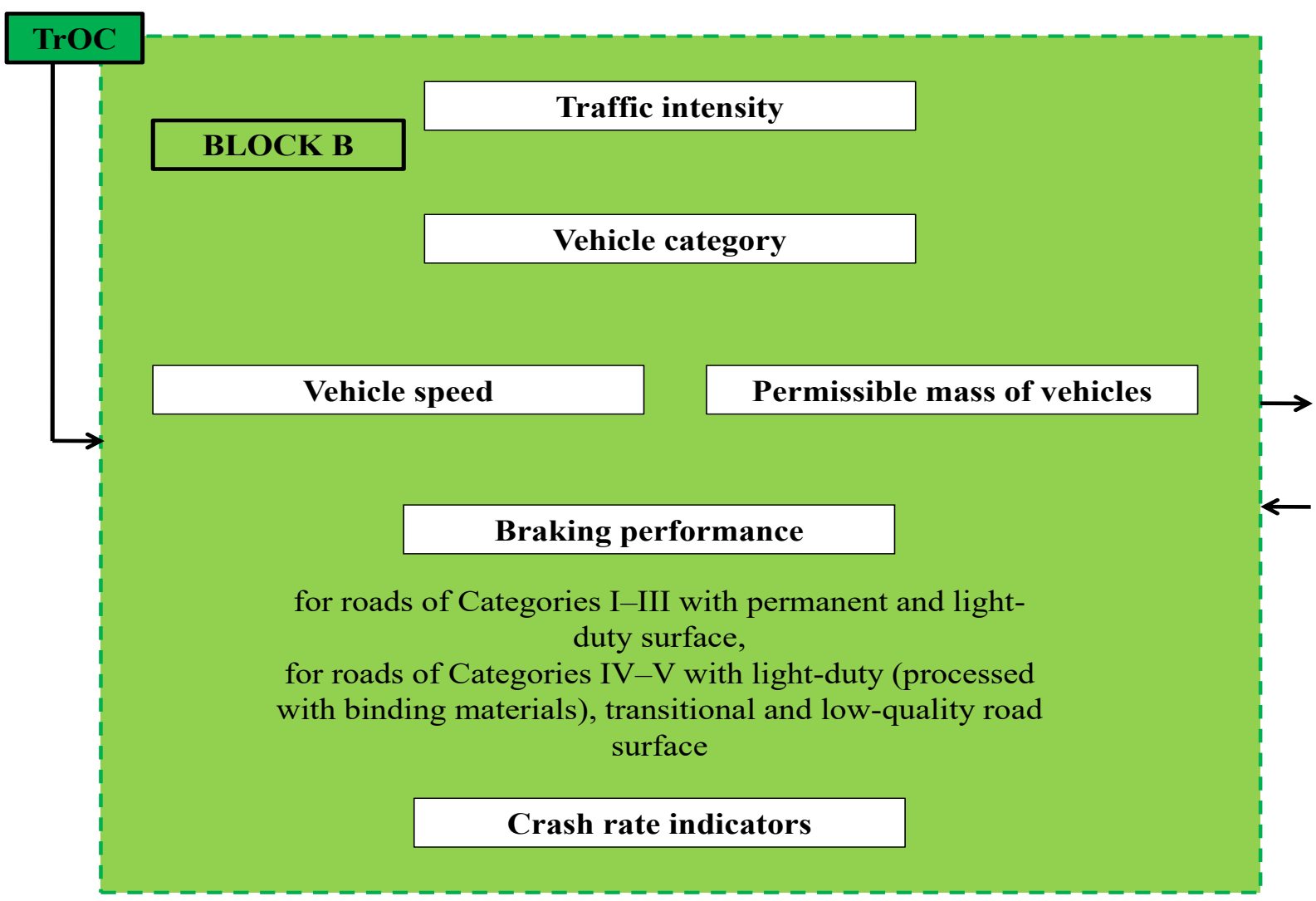

Figure 2. Block B parameters: traffic intensity and vehicle category, speed, permissible mass, crash rate, braking performance

\begin{tabular}{|c|c|c|c|}
\hline TechOC & \multirow{2}{*}{\multicolumn{2}{|c|}{ Adhesion coefficient }} & \multirow[b]{2}{*}{ Roughness } \\
\hline & & & \\
\hline Road surface type & Surface condition & Adhesion coefficient & \multirow{6}{*}{ 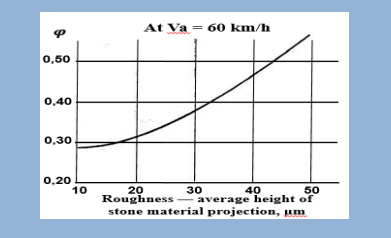 } \\
\hline \multirow[t]{2}{*}{ Asphalt, concrete } & dry/wet & $0.70 \div 0.80 / 0.50 \div 0.60$ & \\
\hline & dirty / snow cover up to $5 \mathrm{~cm}$ & $0.25 \div 0.45 / 0.20 \div 0.40$ & \\
\hline $\begin{array}{l}\text { Cobblestone, paving } \\
\text { stone blocks }\end{array}$ & dry/wet & $0.60 \div 0.70 / 0.40 \div 0.50$ & \\
\hline Soil road & dry/wet/dirty & $0.60 \div 0.70 / 0.20 \div 0.40 / 0.15 \div 0.30$ & \\
\hline Sand & wet/dry & $0.40 \div 0.50 / 0.20 \div 0.30$ & \\
\hline Clayey soil & \begin{tabular}{|l|} 
dry \\
moistened to plasticity \\
\end{tabular} & $\begin{array}{l}0.40 \div 0.50 \\
0.20 \div 0.40\end{array}$ & Hydraulic roughness \\
\hline BLOCK C & \begin{tabular}{|l|} 
moistened to fluidity \\
\end{tabular} & $0.15 \div 0.25$ & \multirow{6}{*}{ 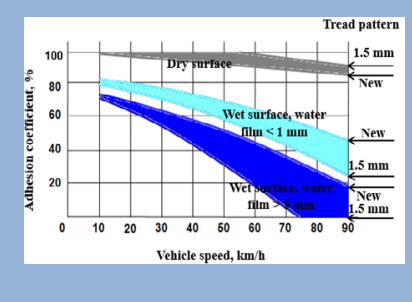 } \\
\hline Meadow, & turfened & $0.10 \div 0.40$ & \\
\hline meadow & & & \\
\hline Snow & 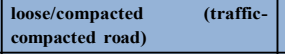 & $0.20 \div 0.40 / 0.30 \div 0.50$ & \\
\hline \multirow[t]{2}{*}{ Ice } & \begin{tabular}{|l|}
$\begin{array}{l}\text { Smooth, at the ambient } \\
\text { temperature below zero }\end{array}$ \\
\end{tabular} & $0.05 \div 0.10$ & \\
\hline & \multicolumn{2}{|c|}{ Wheel tracking } & \\
\hline \multirow[t]{2}{*}{ Vehicle speed } & \multicolumn{2}{|c|}{ Track depth, mm } & \multirow{2}{*}{ Defects of the road surface } \\
\hline & permissible & maximum permissible & \\
\hline$>120$ & 4 & 20 & \multirow{4}{*}{ Elasticity modulus } \\
\hline 120 & 7 & 20 & \\
\hline 100 & 12 & 20 & \\
\hline 80 & 25 & 30 & \\
\hline 60 and less & 30 & 35 & Load-bearing capacity \\
\hline
\end{tabular}

Figure 3. Block C parameters: coefficient of adhesion, wheel tracking, surface roughness, presence of defects, elasticity modulus, load-bearing capacity of the surface 
Block $A$ in Figure 1 (a, b, c, d) includes parameters related to GREF (geometry of road environment facilities). Block $\mathrm{B}$ includes parameters characterizing $\mathrm{TrOC}$ (transport and operating conditions) (Figure 2). Block $C$ in Figure 3 represents parameters that occur under certain technical and operating conditions (TechOC). Coefficient of adhesion of the vehicle tire with the road surface is a multi-value parameter since its values differ for different types of surfaces and conditions. CRIF (characteristics of road infrastructure facilities) in Block $D$ of the expert study accounts for such parameters as the type and condition of artificial structures (bridges, overpasses, tunnels), condition of the pipe culvert system, presence of driver location signs, lighting, railroad crossings, availability of properly functioning means of technical organization of road traffic (MTORT).

Obtaining information on values of parameters of technical condition of vehicles and road infrastructure, including GREF, TrOC, TechOC and SRIF, is possible with the help of diagnostic equipment. Regulatory sources were used in compiling Blocks A-C, as well as Block D.

The dependence of the expert study, conducted by a diagnostic method, during which parameters of the "Vehicle-Road" subsystem condition were determined, has the following form:

$$
\begin{aligned}
& \mathrm{Y}\left(X^{D}\right)=f\left(N_{i}, W_{\text {pull. }}, W_{m \text { arg. }}^{\text {sh. }}, W_{\text {div.str. }}^{\text {cent. }},\right. \\
& S_{\text {marg }}^{\text {sh }}, L_{\text {stop. }}, i, i_{\text {trans }}, i_{r}, R_{\text {curve }}, S_{c l}, R_{\text {convex }}, R_{\text {concave }}, \\
& Z, h_{f}, L_{\text {slope }}, I_{v e h}, M_{1} \div O_{2}, V_{a}, G_{\text {veh }}, K_{P}^{I-V}, \\
& N_{a c c}, A C C_{a b s}, A C C_{r e l}, \varphi, t, r, r_{h}, E \\
& \left.D_{\text {r.s. }}, T_{\text {a.s. }}, T_{\text {drain }}, T_{\text {loc }}^{\text {signs }}, T_{\text {light }}, T_{\text {rail }}, M T O R T\right),
\end{aligned}
$$

where $N_{i}$ is the number of lanes; $W_{\text {pull }}$ is the pullover width, m;

$W_{m a r g}^{s h}$ is the width of the shoulder margin strip, m; $W_{\text {div.str. }}^{\text {cent }}$ is the width of the central dividing strip, $\mathrm{m} ; S_{m \text { arg }}^{s h}$ is the margin strip of the shoulder, $\mathrm{m}$;

$L_{\text {stop }}$ is the stopping strip, $\mathrm{m} ; i$ is the longitudinal grade, per mille; $i_{\text {trans }}$ is the transverse grade, per mille; $i_{R}$ is the raised curve grade, per mille; $R_{\text {curve }}$ is the curve radii in plan, $\mathrm{m} ; S_{c l}$ is the clear vision distance to the object, $\mathrm{m}$; $R_{\text {convex }}$ is the radii of convex curves in profile, $\mathrm{m} ; R_{\text {convex }}$ is the radii of convene curves in profile, $m ; Z$ is the structure of the road bed; $h_{f}$ is the depth of fill, $\mathrm{m} ; h_{e}$ is the depth of excavations, $\mathrm{m} ; L_{\text {slope }}$ is the slope grade; $I_{v e h}$ is traffic intensity, vehicles/day;

$\mathrm{M} 1 \div \mathrm{O} 2$ are the categories of vehicles from $\mathrm{M} 1$ to $\mathrm{O} 2$; $\mathrm{Va}$ is the vehicle speed, $\mathrm{km} / \mathrm{h}$; Gveh is the vehicle mass, $\mathrm{t}$; is the coefficient of braking performance of the vehicle; Nacc is the number of road accidents; ACCabs is the absolute crash rate; ACCrel is the relative crash rate; $\varphi$ is the coefficient of adhesion of the vehicle tire with the road surface; $t$ is the depth of the road track (wheel tracking), $\mathrm{cm} ; r$ is the roughness of the road surface, average height of material projection, $\mu \mathrm{m}$; rh is the hydraulic roughness; $\mathrm{E}$ is the modulus of elasticity, MPa; Dr.s. are defects of the road surface; Ta.s. are artificial structures; Tdrain is the condition of the drainage system; is presence of driver location signs; Tlight is availability of lighting; Trail is presence of railway crossings; MTORT is equipping with technical means of road traffic organization.

The algorithm for implementing the procedure in order to increase the reliability of determination of circumstances and causes of road accidents is presented in the form of a block diagram of successive stages (Figure 4). It is necessary to determine tasks and objectives of the examination and desired results before the study.

Obtaining of the input data or additional information on parameters of vehicles and road infrastructure is possible with the help of diagnostic equipment; requirements and characteristics are presented in Blocks A-D. An important step is to determine the compliance of the actual parameters obtained. It is determined following their comparison with the standard values and establishment of deviations of the obtained values from the reference ones. Thus, the opportunity to define causes of the road accident more precisely increases.

Evaluation of actual values of parameters of vehicle and road infrastructure condition is carried out by means of their comparison with the reference values, which are standard. This allows for the identification of the guilty party of the accident. For example, the cause of an accident is in defects of the road surface (pits, potholes), and their geometric parameters do not meet the requirements of legal documents. The guilty party in this case is the road organization or service that failed to timely repair the dangerous site. Thus, untimely work of road maintenance services in winter (ice, snow) would also increase the risk of accidents. Therefore, recording of parameters and qualitative analysis of the accident site are important aspects in compilation of information about the accident and case materials (Kurakina et al., 2017; Federal State Budgetary Institution ROSDORNII, 2015).

Wheel tracks, deflections of the road surface and changing of the surface condition during operation also contribute to the increase of accidents. Periodic monitoring and assessment of technical condition of operated road surfaces are essential for ensuring the operational status and throughput of roads. Therefore, the necessity to carry out road accident investigation and, as a result, assessment of the road surface condition and determination of its residual life, are substantiated. The following criteria are suggested to identify "weak" sections of roads:

- the hazard level of road sections;

- the level of accident stability;

- safe traffic conditions;

- service life of the road surface.

Measurement and determination of each of the criteria are based on condition and service life parameters.

The developed algorithm for expert examination of road accidents in a non-destructive manner would allow 


\section{Architecture and Engineering Volume 2 Issue 3}

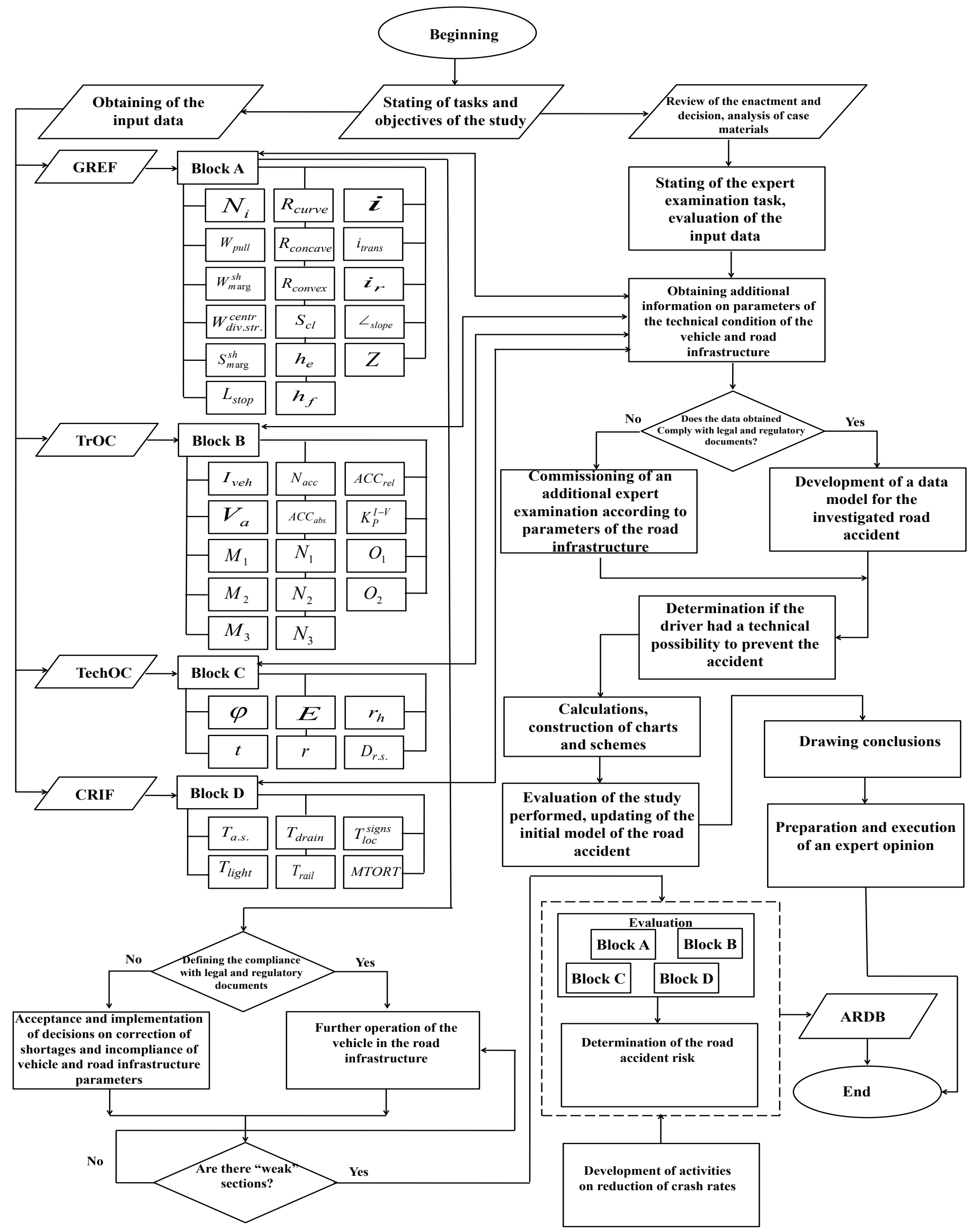

Figure 4. Algorithm of the expert study in a non-destructive manner 
solving problems in many areas, taking into account the interaction of complex structures with a multitude of parameters - with regard to vehicles and road infrastructure. agnostic studies are carried out by setting dynamic loads with Dynatest FWD (Kurakina, 2016, 2017).

The basis of the algorithm of expert studies in a non-destructive manner for revealing "weak" sections of roads is the new industrial guidance document "Recommendations for accounting and analysis of road accidents on the roads of the Russian Federation". According to this document, assessment of the general crash rate and trends in its change is carried out; sections of the concentration of accidents are identified; characteristic types of road accidents are determined for the sections of their concentration; effective management decisions and measures to improve traffic safety at the sections of road accidents are developed (Federal State Budgetary Institution ROSDORNII, 2015).

Determination of the accident risk is based on the establishment of factors contributing to an emergency situation. The studies risk factors include parameters of vehicle and road infrastructure condition, presented earlier, and conditions of their operation (time period, weather, climate and spatial conditions). Thus, the more information is analyzed and actual values are obtained, the fuller and more accurate are the results of determining emergency and accident risks, as well as the results of expert examination.

The automated road data base (ARDB) currently exists in the form of software products of individual organizations that perform diagnostics and assessment of technical and operating conditions and parameters of motor roads. However, the analyzed sources do not provide information on road sections characterized by high accident rate, low quality of the road surface and structural layers, life cycle of which is not large considering these parameters in the aggregate, that is, "weak" road sections. Introduction of this concept into practice will increase the information value of the status of the road data necessary for conducting expert studies.

\section{Conclusion}

In order to improve the system for accounting different parameters during construction of motor roads, it was suggested to take into account qualitative and quantitative characteristics of the traffic flow, vehicle braking processes, strength of the road surface by the elasticity modulus, determination of accident concentration sections by the risk of their occurrence, as well as their impact on prediction of the crash rate. Analysis of the technical characteristics of the non-destructive equipment and engineering measurements in determination of the parameters of the "Vehicle-Road" subsystem made it possible to select the diagnostic unit Dynatest FWD, substantiating such choice with the purpose, actualness and relevance of its practical application, safety of engineering measurements, convenience, speed of obtaining and processing of information, and a high possibility to analyze the entire range of the studied parameters.

In order to obtain a complete solution of the set tasks, more comprehensive parameters of the "Vehicle-Road" subsystem condition were proposed to make it possible to predict the occurrence of the road accident risk, including accident concentration sections, as well as to increase the reliability of conclusions and accuracy of calculations in expert opinions.

The developed procedure of expert studies in a non-destructive manner allows expanding the ways to ensure road safety and, consequently, increasing the overall effect of the road safety increase by introducing additional and previously not accounted factors into the study. 


\section{References}

Domke, E.R. (2012). Rassledovanie i ekspertiza dorozhno-transportnykh proisshestvii [Investigation and expert examination of road accidents], 2nd edition. Moscow: Publishing Center "Akademia", p. 288. (in Russian)

Evtyukov, S.A., Vasiliev, Ya.V. (2012). Dorozhno-transportnye proisshestviia: rassledovanie, rekonstruktsiia, ekspertiza [Road accidents: investigation, reconstruction, expert examination]. Saint Petersburg: Publishing House "DNK", p. 392. (in Russian)

Federal State Budgetary Institution ROSDORNII (2015). Rekomendatcii po uchetu i analizu dorozhno-transportnykh proisshestvii na avtomobilnykh dorogakh Rossiiskoi Federatcii. ODM 218.6.015-2015 [Recommendations for accounting and analysis of road accidents on the roads of the Russian Federation. ODM 218.6.015-2015]. (in Russian)

Ilarionov, V. A. (1989). Ekspertiza dorozhno-transportnykh proisshestvii [Expert examination of road accidents]. Moscow: Transport, p. 255. (in Russian)

Kurakina, E. V., Evtyukov, S. A. (2014). Sovershenstvovanie algoritma avtotekhnicheskoi ekspertizy pri rekonstruktsii DTP, uchityvaiushchei tekhnicheskoe sostoianie transportnogo sredstva i dorogi [Improvement of the algorithm of technical expert examination of motor vehicles during reconstruction of road accidents with account for the technical condition of vehicles and roads]. In: Proceedings of the 11th International Conference "Organization and Traffic Safety Management in large cities", pp. 518-527. (in Russian)

Kurakina, E. V., Dobromirov, V. N., Evtyukov, S. S. (2017). Sovershenstvovanie metodov otsenki bezopasnosti dorozhnogo dvizheniia na skorostnykh avtomobil'nykh dorogakh [Improvement of methods for assessing road safety on high-speed roads]. The World of Transport and Technological Machinery, 1 (56), pp. 94-101. (in Russian)

Kurakina, E., Evtyukov, S., Lukinskiy, V., Ushakov, A. (2017). Methodology for the reconstruction and investigation of causes of accidents in the parameters of vehicle condition and road environment. Transportation Research Procedia, 20, pp. 185-192. DOI: 10.1016/j.trpro.2017.01.049

Kurakina, E. V. (2013). Ekspertnaia kharakteristika avtomobilnoi dorogi v dorozhno-transportnoi ekspertize [Expert review of roads in road traffic expert examination]. Modern problems of science and education, 5. Available at: http: //www.science-education. ru/111-r10273 (accessed on: 29.06.2017). (in Russian)

Kurakina, E. V. (2014a) Nauchno-metodicheskoe obespechenie avtotekhnicheskoi ekspertizy, uchityvaiushchei tekhnicheskoe sostoianie avtomobilia i dorozhnoi sredy [Scientific and methodological support of technical expert examination of motor vehicles with account for the technical condition of vehicles and road environment]. PhD Thesis in Engineering. Saint Petersburg, p. 203. (in Russian)

Kurakina, E. V. (2014b). Issledovanie sostoianiia bezopasnosti i kachestva podsistemy [Investigation of safety and quality of the "Road" subsystem]. In: Proceedings of the International Scientific and Technical Conference "Engineering Science 2014: theory, education, practice and innovations", pp. 232-244. (in Russian)

Kurakina, E. V. (2014c). Ob otklonenii normativnykh kharakteristik pokazatelei avtomobil'noi dorogi (na primere avariino-opasnykh uchastkov dorog Leningradskoi oblasti) [On deviations of standard characteristics of the road (case study of accident clusters of roads in the Leningrad Region)]. Modern problems of science and education, 2, p. 118. (in Russian)

Kurakina, E. V. (2016). Diagnosticheskoe issledovanie elementov avtomobil'nykh dorog na uchastkakh DTP nerazrushaiushchim kontrolem [Diagnostic work-up of the motor road elements at the site of traffic accident by nondestructive testing technique]. Vestnik grazhdanskikh inzhenerov [Bulletin of Civil Engineers], 6 (59), pp. 231-237. (in Russian)

Kurakina, E. V. (2017). Sovershenstvovanie algoritma dorozhno-transportnogo issledovaniia nerazrushaiushchim metodom [Improvement of the algorithm of road and transport investigation in a non-destructive method]. Vestnik grazhdanskikh inzhenerov [Bulletin of Civil Engineers], 1 (60), pp. 262-269. (in Russian)

Kurakina, E.V., Evtyukov, S.S. (2015). Issledovanie stsepnykh kharakteristik dorozhnogo pokrytiia pri avtotekhnicheskoi ekspertize DTP [Study on adhesion characteristics of the road surface in auto technical examination of the road traffic accident]. Vestnik grazhdanskikh inzhenerov [Bulletin of Civil Engineers], 5 (52), pp. 216-223. (in Russian)

Kurakina, E. V., Evtyukov, S. S., Golov, E. V. (2017). Rekonstruktsiia dorozhno-transportnykh proisshestvii [Reconstruction of road accidents]. Saint Petersburg: Publishing House "Petropolis". (in Russian)

Nemchinov, M. V. (1985). Stsepnye kachestva dorozhnykh pokrytii i bezopasnost' dvizheniia avtomobilia [Adhesion characteristics of road surfaces and road safety]. Moscow: Transport, p. 231. (in Russian)

Suvorov, Yu. B., Kikot, I. M., Khapatnyukovsky, M. V., Kovalenko, L. A., Kilienko, I. I. (1990). Diagnosticheskoe issledovanie elementov avtomobil'nykh dorog na uchastkakh dorozhno - transportnykh proisshestvii (dorozhnykh uslovii), vliiaiushchikh na bezopasnost' dorozhnogo dvizheniia [Diagnostic study of road elements at sections of high accident rate (road conditions) affecting road safety]. Moscow: All-Union scientific research institute of judicial investigation, p. 96. (in Russian)

Vasiliev, A. P. (2005). Spravochnaia entsiklopediia dorozhnika [Encyclopedia for road workers], vol. 1. Moscow: Informavtodor. (in Russian) 